\title{
Assessment of exogenous geological hazards in Moscow, Russia
}

\author{
*Olga Eremina, Irina Kozliakova, Nadezhda Anisimova, and Irina Kozhevnikova \\ Sergeev Institute of Environmental Geoscience, Russian Academy of Sciences (IEG RAS), Moscow, Russia \\ *Corresponding author: sci-council@geoenv.ru
}

\begin{abstract}
Exogenous geological processes are exerting a significant impact on urban geoenvironment in Moscow endangering both surface and subsurface constructions. For surface construction, the principle geohazards in Moscow are karst-suffosion sinkholes, land subsidence, landslides, and waterlogging. The subsurface construction is endangered by karstification and fracturing of limestone, decompaction and swelling of clay, quicksand phenomena, and groundwater breakthrough to tunnels. Different methods are applied to study geohazards depending on the purpose and the scale of study. At the preliminary investigation stage, small-scale mapping and zoning of city surface or subsurface appears to be the most appropriate for the qualitative assessment of the risk of economic losses caused by exogenous geohazards. Assessment of the geological risk in Moscow was carried out separately for already existing urban infrastructure and for future planned construction. For existing surface urban infrastructure, geological risk is considered to be an integral parameter of probable damage caused by geohazards and the anthropogenic load on the specific territories. The main aim of risk mapping in this case is outlining the territories, for which restrictions and prohibitions should be imposed for further urban engineering development. For future subsurface urban construction, the risk-analysis consists in assessing the impact of geohazards on the engineering structure by comparing the future expenditures for the construction and operation under different engineering geological conditions. The risk maps in this case will help planners to compare and make alternative project decisions in order to minimize the cost in future economic expenditures. Both approaches are successfully approved in this investigation in Moscow.
\end{abstract}

Keywords: Exogenous geohazards, Risk-analysis, Urban areas, Mapping, Urban environment vulnerability

Paper Received: 31 Jan 2018

Paper Accepted: 10 March 2018

\section{INTRODUCTION}

Sustainable urban development of Moscow is based on the balance between ecological and socio-economic demands, rational nature use and improvement of ecological situation. Exogenous geological processes exert a significant impact on the geoecological condition of urban area, because of being widespread they complicate both surface and underground engineering construction as well as the operation of existing buildings and other engineering structures. Intensification of exogenous geological processes may pose immediate danger to urban infrastructure stability and even to human health and loss of lives. Now it is commonly recognized among urban geologists that the assessment of geohazards alone is not enough for urban planning. In order to ensure the sustainable development of cities, it is necessary to start from the estimation of geohazards and pass to the assessment of geological risk. Actually, it is risk analysis that provides an adequate idea about the size of possible economic loss caused by geohazards in an urban area. The development of technology and working procedure of assessing risk caused by the hazardous geological processes is the most important task for urban geologists. Due to geodata uncertainties, this problem seems to be hardly solved on a quantitative level (Knill, 2003; Clayton, 2009; Kalsnes et al., 2010). Almost all researchers involved in risk assessment in urban areas agree that the combination of geohazard maps with the maps of urban environment vulnerability is the most promising approach to the georisk assessment in cities (Marchiori-Faria et al., 2006; Zhang et al., 2006; Mora, 2010). So far, assessment and mapping of exogenous geological hazards is the first step in georisk analysis in urban areas. As applied to Moscow area, the exogenous geohazards that affect the urban geoenvironment originate from its peculiar geological setting and engineering geological conditions.

\section{ENGINEERING GEOLOGICAL CONDITIONS IN MOSCOW}

Engineering geological conditions in the Moscow region have been comprehensively studied before by many previous researchers (Golodkovskaya and Lebedeva, 1984; Medvedev, 1997; Koff et al., 2006; Osipov and Osipov 2008 and 2014; Kutepov et al., 2011; Kozlyakova et al., 2015 and 2016). Geomorphologically, Moscow is located within three natural geographical regions, i.e., Smolensk-Moscow upland in the northwest, Meshchera lowland in the east, and Teplyi Stan upland in the south-southwest. These regions are divided by the valleys of the Moscow and the Yauza rivers. Within the city territory, the Moscow River valley consists of the floodplain and three alluvial terraces lying above the floodplain. The surface topography has been transformed substantially in the city by technogenic impact. Many minor rivers and creeks were removed from the surface to flow in underground pipes. Gullies were backfilled; the outlines of river banks were modified, as 
well as the depth and width of the Moscow and the Yauza River channels; the water level in the Moscow river was raised; and the absolute elevations of the terrace and floodplain surfaces were altered by levelling and backfilling by human activities. The floodplain was partially flooded.

In terms of geology, Moscow is located within a vast syncline in the center of the East European platform covered by a thick mantle of sedimentary deposits. Within the depth of technogenic impact, the sedimentary mantle in Moscow area consists of stratified Carboniferous, Jurassic, Cretaceous, and Quaternary deposits of various genesis. Geological structure of Moscow is extremely variable (Fig. 1). This variability arises mainly due to the river erosion and it is pronounced in abrupt fluctuations of thickness and lithological composition of soil and rock complexes.

The mid- and upper Carboniferous limestone, marl and clay occur at a depth 5-150 m. Carbonate deposits are intensely fractured and karstified. Limestone, dolomite, marl and clay of Carboniferous age are overlain by Meso-Cenozoic sandy-clayey deposits. Carboniferous deposits underlie immediately the

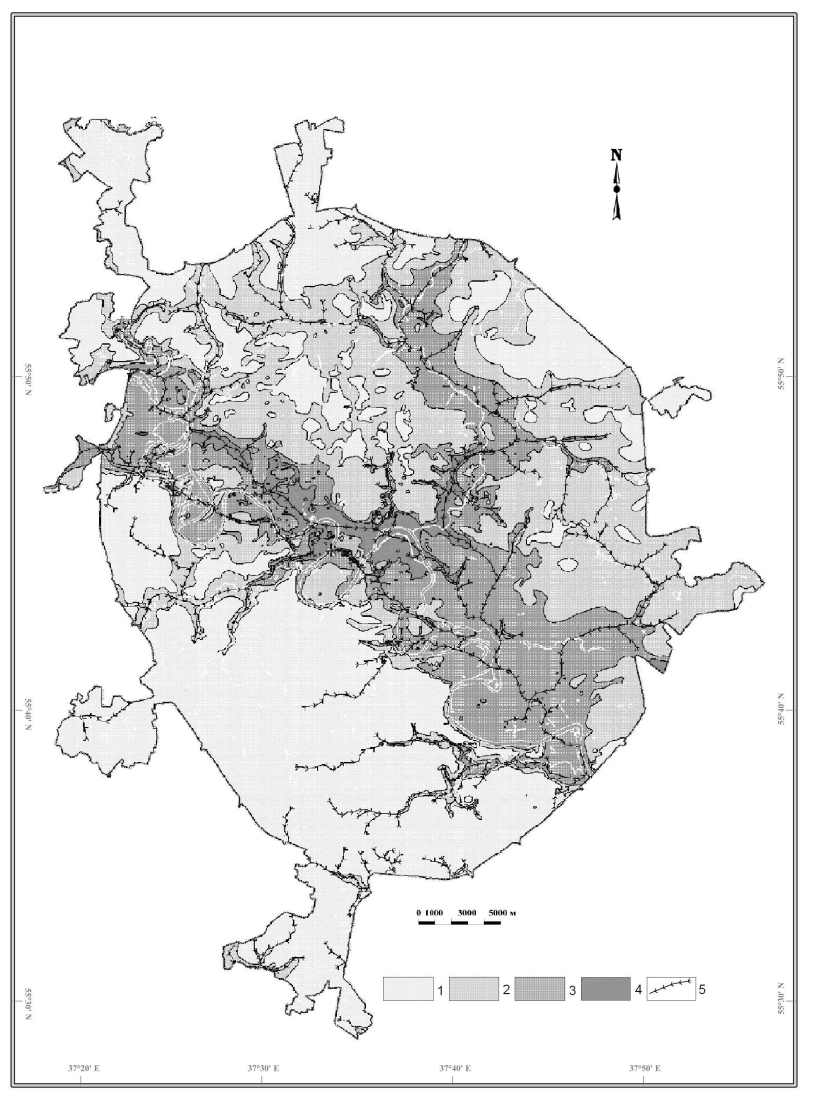

Fig. 1: Geological map and geological cross-section of the Moscow territory. Designations: 1 -Cretaceous deposits, 2 - upper Jurassic deposits, Tithonian stage, 3 - mid- and upper Jurassic deposits (Oxfordian, Callovian, and Bathonian stages), 4 - Carboniferous deposits, 5 - thalwegs of preglacial erosional cuttings.
Quaternary deposits in thalwegs and slopes of preglacial and modern river valleys. The Mesozoic deposits consist of midJurassic continental deposits of Bathonian and Callovian stages, marine sandy-clayey mid- and upper Jurassic deposits, marine sandy-clayey mid- and upper Jurassic deposits of Callovian, Oxfordian and Tithonian stages, as well as marine mainly sandy deposits of Cretaceous system. Bathonian and Callovian deposits are represented by interlayers and lenses of dark gray and brown sand, loam and sandy loam with coal inclusions and interlayers and lenses of sand. Bluish gray and brown dense clay with sandy interlayers also occur locally. The thickness of BathonianCallovian strata rarely exceeds $10 \mathrm{~m}$. These deposits are preserved in the local depressions of the Carboniferous massif roof. They are overlain by middle and upper Jurassic Callovian and Oxfordian clay, or sporadically, by Quaternary sand, sandy loam and loam. Callovian and Oxfordian clay were deposited during the Jurassic sea, which spread over the entire Moscow territory. Once the sea retreated, the continuous mantle of these deposits overlying the Carboniferous massif covered the entire territory of Moscow. They were eroded later in Cenozoic era by the rivers. The preserved thickness of Jurassic clay varies significantly. It depends on the preJurassic subcrop topography, with maximum thickness $(50 \mathrm{~m})$ in the central part of the Main Moscow depression in the south of the city; whereas this thickness rarely exceeds $10 \mathrm{~m}$ at the preJurassic watersheds in the north of the city. These are dark gray and black homogenous dense micaceous clay with few fossil fragments. On the preglacial watersheds, Callovian and Oxfordian clay are overlapped by marine sandy-clayey Tithonian deposits; whereas in the preglacial valleys, this clay underlies the lower and middle Quaternary alluvial and fluvioglacial sands.

Marine sand and clay of Tithonian age are preserved only on the preglacial watersheds, where they overlie discordantly the Callovian-Oxfordian clay. The thickness of the Tithonian strata ranges from $0-1$ to $10-30 \mathrm{~m}$ depending on the preglacial topography, with the maximal thickness being registered in the southwest of Moscow (within the Teply Stan elevation). Cretaceous deposits are preserved and uneroded predominantly in the south and southwest of Moscow, where they compose preQuaternary and modern interfluves. They are represented by up to $40 \mathrm{~m}$ thick marine deposits overlying the Tithonian upper Jurassic strata. The bottom of the Cretaceous massif is composed of brown, dark gray and greenish gray sands and sandstones with pebbly phosphorite layer at the basement. Upward by the cross-section, they are replaced by black and dark gray clay, which is overlain by light yellow and yellowgray fine-grained sand with very few thin interlayers of loose sandstone. Cretaceous deposits are overlain by the Quaternary strata.

Quaternary deposits are represented by moraine loam of three glaciation periods; interfluvial (mainly sandy) deposits; alluvial sands of three terraces above the floodplain of the Moscow River and its tributaries; as well as technogenous deposits. The thickness of the Quaternary deposits ranges from few meters to $50 \mathrm{~m}$. It's maximum thickness is registered in the 
south and southwest of Moscow, where the erosion activity of the modern river network was the weakest. The Quaternary strata are very thick within the deep preglacial valleys filled with fluvioglacial sand (Fig. 1). The Technogenous deposits cover almost the entire city territory, with their thickness reaching $15-20 \mathrm{~m}$.

Groundwater aquifers in Moscow area are confined to the Quaternary and Mesozoic sandy and sandy-loamy deposits, as well as to Carboniferous limestone massif. In the areas, where low-permeable moraine loam strata occur, the following aquifers are distinguished: (a) above-moraine unconfined aquifer, and (b) intra-moraine and under-moraine (often confined) aquifers. In the areas, where moraine is absent, the Quaternary groundwater aquifer is unconfined as a rule. Mesozoic aquifers may be both unconfined and confined. Fractured karstic aquifers in Carboniferous limestone showed a high hydraulic head in Moscow in the early 20th century. However, intense water extraction in the 20th century lowered their head significantly, and at present, the upper water horizons in Carboniferous limestone massif are mainly unconfined. However, the deep Carboniferous aquifers may show the hydraulic head up to $25 \mathrm{~m}$.

Due to the specific engineering geological structure of Moscow, the city territory is subjected to a number of exogenous geological processes (EGP). The principle exogenous geohazards in Moscow are karst-suffosion sinkholes, land subsidence, landslides, and waterlogging. Karst and suffusion most often develop in thalwegs and on slopes of preglacial valleys, where the upper Jurassic clay is partially or completely eroded. Upon certain hydrodynamic conditions the clay stratum may be destroyed, and the suffosional downward flow of sand to karstic caverns and fractures in limestones may be triggered. This process results in sinkhole formation on the surface. Karts and suffusion develop most intensely in the northwest of Moscow, were the preJurassic and preglacial channels have eroded partially or completely the overlying Mesozoic deposits. Limestone is highly karsitified there, and more than 40 karst sinkholes are registered in that area (Kozlyakova, 2016).

Landslides are mostly confined to the slopes of the Moscow river valley and its tributaries. One can distinguish deep landslides with a slipping surface confined to the Jurassic clay and shallow landslides confined in Quaternary deposits only. Deep landslides affect 15 slopes in the Moscow river valley within the city boundaries. Surface landslides are more widespread. They are registered both in the areas disturbed by major landslides and in the valleys of minor rivers, brooks, and gullies. Waterlogging development is controlled by the modern topography in Moscow. The areas, within which the uppermost aquifer occurs at a depth of less than $3 \mathrm{~m}$ are considered to be waterlogged. These are mainly floodplains of the Moscow River and its tributaries. The perched groundwater horizons may form in watershed areas, where moraine loam is preserved. The areas, within which the groundwater level occurs at a depth 3-5 $\mathrm{m}$, are considered as potentially prone to waterlogging. Permanently waterlogged areas occupy about $30 \%$ of Moscow; and $25 \%$ of territory may be classified as potentially prone to waterlogging (Osipov, 2014).

The above-mentioned EGPs exert a significant impact on geoenvironment of Moscow affecting the urban infrastructure. They should be taken into consideration upon both surface and subsurface construction. The subsurface construction is endangered by karstification and fracturing of crystalline limestone, decompaction and swelling of clay, quicksand phenomena, and groundwater breakthrough to tunnels.

\section{APPROACHES TO GEOHAZARD AND RISK ASSESSMENT IN MOSCOW}

Geological risk is defined as the qualitative or quantitative measure of a geological hazard or a number of hazards determined for a particular object or particular territory in the form of possible absolute or relative economic losses (damage) (Ragozin 2003; Ragozin and Yolkin 2006). This definition suggests that risk is a function of the hazard impact value and the engineering structure (territory) vulnerability.

The authors applied different methods for the study of geohazards operating in Moscow depending on the purpose and the scale of the study. For the preliminary stage of investigation, to a small scale, special mapping and zoning of city surface or subsurface environment appears to be the most appropriate; whereas, at the follow up stages of survey mapping is combined with the calculation and analytical methods.

In authors' view point, the risk of economical loss caused by exogenous geological hazards in cities should be assessed separately for already existing urban infrastructure and for future planned construction. In both cases, upon mapping the qualitative comparative assessment of geological risk is made (Fig. 2). For existing infrastructure, the main aim of risk mapping is to outline the territories, for which special requirements should be laid on engineering survey, as well as restrictions and prohibitions should be introduced on urban engineering development. For future construction, the risk maps permit comparing alternative project decision variants in order to minimize economic losses from geological hazards upon the construction and operation of buildings and other engineering structures. Both approaches have been tested in Moscow.

\section{ASSESSING GEOHAZARDS AND GEORISK FOR THE EXISTING URBAN INFRASTRUCTURE}

For assessing georisk that is caused by exogenous geohazards for the existing infrastructure, we have developed the mapping procedure that involves the following steps:

- assessment and mapping of exogenous geological processes (EGPs) according to the degree of hazard;

-assessment and mapping of urban environment vulnerability to EGPs (where the urban environment is taken to mean the city territory with buildings and onsurface engineering facilities); 


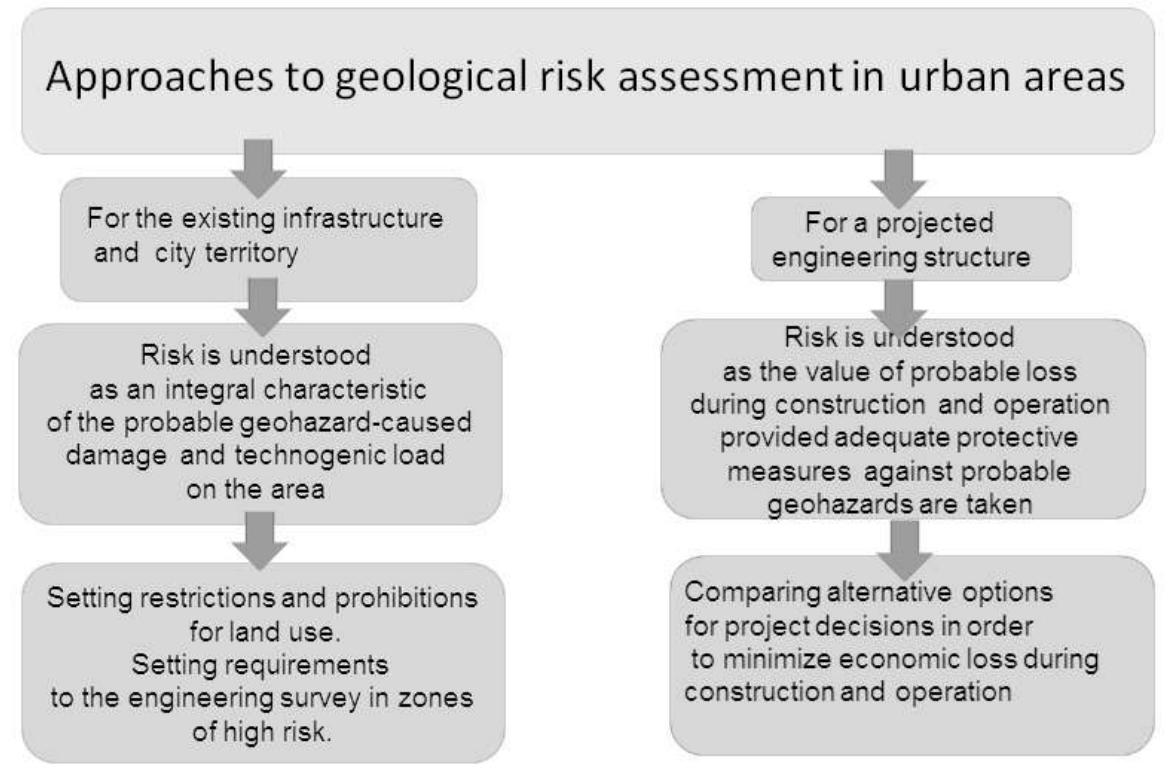

Fig. 2: Two approaches to the georisk assessment in urban areas

-distinguishing risk categories by the analysis of the hazardous geological processes affecting the city territory and surface urban infrastructure;

- compilation of the risk map by superposition of the integral map of EGPs hazard and the map of urban environment vulnerability.

The qualitative comparative assessment and geological risk mapping were performed on the basis of integral assessment of EGP hazard and the functional zoning of city territory. The integral hazard assessment implies revealing the possible adverse changes in urban environment and obstacles to construction and operation of buildings and engineering structures in the areas of EGPs development and the subsequent typification of the territory by its favorability. The "Map of geoecological state of the Moscow territory (assessment of hazardous exogenous geological processes) prepared in a scale $1: 50$ 000, is taken as the basis of this assessment (Kozlyakova et al., 2015). Here, the object at risk is the urban environment, which includes the city territory with the surface infrastructure.

As was mentioned above, the most hazardous EGPs in Moscow are landslides (deep, above all), as well as karst and suffosion collapses and surface subsidence. These processes cause damage or ruining of buildings, leading sometimes to catastrophic consequences. Waterlogging is another geological process developing in Moscow, which is less hazardous to buildings and engineering structures. However, being a permanently acting factor widespread by the area, waterlogging may cause substantial economic damage to the city. Five categories of geoecological state are distinguished in the Moscow territory from the comprehensive analysis of the above-mentioned EGPs, i.e., favorable, conventionally favorable, conventionally unfavorable, unfavorable, and very unfavorable (Fig. 3).
The functional zoning of Moscow territory includes 5 types of functional zones: transport, recreational, industrial, social (public), and residential (Fig. 3). In this way, this zoning gives us a tentative idea about the vulnerability of separate parts of the city to the hazardous EGPs. The density of territory building-up with on-surface permanent engineering structures usually increases in the row: recreational - transport - industrial - public - residential zones. These parameters appear to be one of the most vivid and reliable characteristics of urban territory vulnerability. The classification is based on the density of territory building-up with on-surface permanent engineering structures as well as on the degree and type of EGPs' impact on urban environment. Risk categories are distinguished depending on the level of possible loss caused by the manifestation of individual processes or their combinations.

Therefore, to the first approximation, the idea about the geological risk in Moscow can be obtained from the superposition and the analysis of geoecological conditions (hazardous EGP), the functional zoning of the territory and the distinguished risk categories (Fig. 4).

In this analysis, estimation and mapping of vulnerability of urban territory and its infrastructure seems to be the most difficult problem. Functional zoning surely gives only tentative and rough index of vulnerability. Therefore, now one can only speak about the schematic risk map for the existing urban infrastructure. The comprehensive procedure of vulnerability analysis should include the estimation of density, type, and age of housing development as well as the assessment of geohazard impact on the urban environment.

On the basis of the developed georisk assessment procedure, the authors have compiled the schematic geological risk map for the existing infrastructure in Moscow arising from 


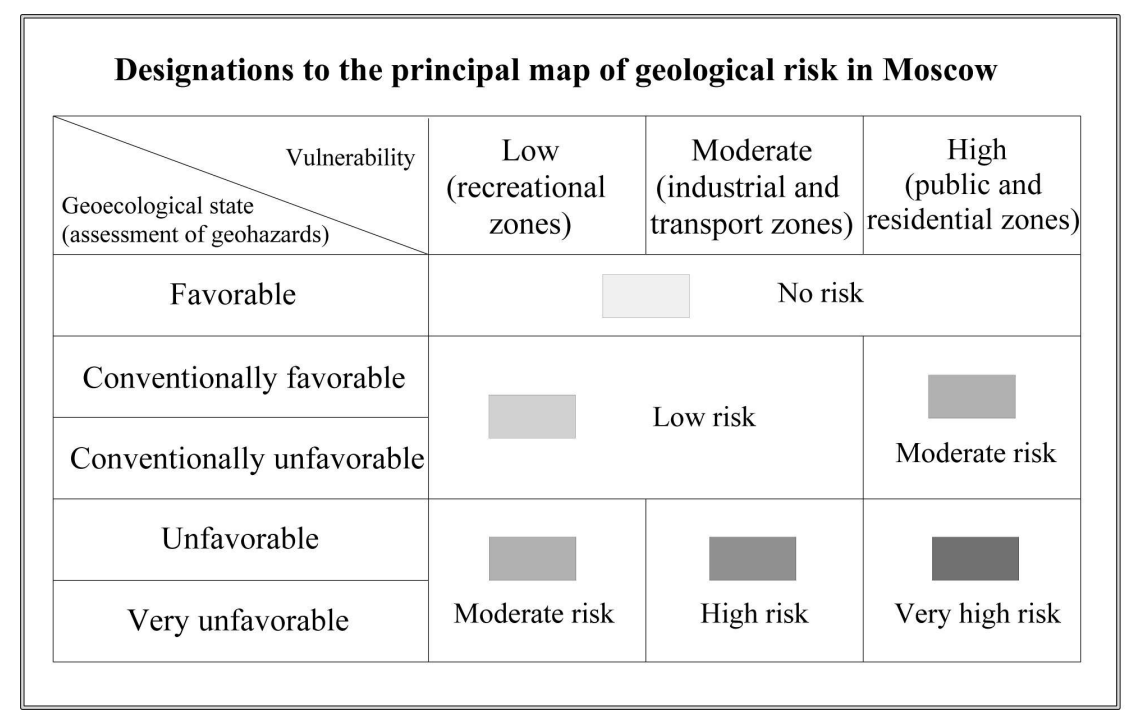

Fig. 3: The schematic state and functional zones of geological risk map in Moscow

EGPs to a scale of 1:50000. This map shows the risk as comparative integral characteristics of the probable damage caused by the geological hazards as well as the level and type of the technogenic load of the territory (Fig. 5).

\section{ASSESSING GEOHAZARDS AND GEORISK FOR THE FUTURE SUBSURFACE CONSTRUCTION}

The risk of losses for a particular engineering structure at the stage of its construction may be analyzed only qualitatively by assessing the impact of geohazards on this engineering structure, since the value of engineering structure vulnerability will be the same in this case. Assuming that this engineering structure may be built in different engineering geological conditions, the risk will be characterized by the possible damage caused by geohazards within the areas of a certain type of engineering geological conditions. Upon this approach, the qualitative risk-analysis in this case may be reduced to assessing the impact of geohazards on the given engineering structure by comparing the future expenditures for its construction and operation under different engineering geological conditions.

For instance, for a projected metro tunnel driven at a shallow depth by an open-pit method, we propose the following risk-assessment procedure. It consists of the following steps:

1. To know the geological structure and hydrogeological conditions in the foot and walls of the tunnel at the planned construction depth proceeding from the $3 \mathrm{D}$ model of geoenvironment.

2 . To typify the engineering geological conditions and the analysis of geohazard impact on the engineering structure for each type of engineering geological conditions;

3. To determine the possible losses (expenditures) during the construction and operation of the facility;

4. To distinguish and substantiate the comparative qualitative categories of risk;

5. To build the map of geological risk.

During present study, the authors distinguish three main groups of ground conditions that one can come across in the bottom and walls of the shallow metro tunnel driven by an

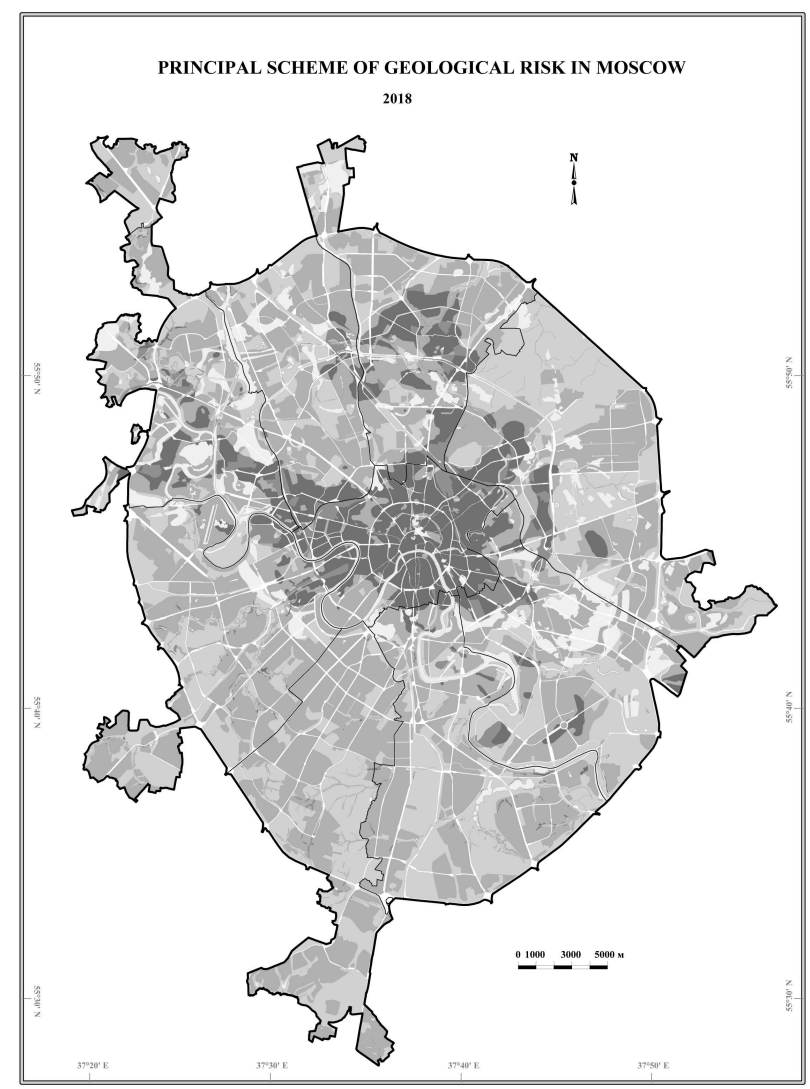

Fig. 4: The schematic map of geological risk for existing urban infrastructure in Moscow. See Fig. 3 for designations. 


\begin{tabular}{|l|l|l|l|}
\hline \multicolumn{1}{|c|}{$\begin{array}{c}\text { Deposits in the } \\
\text { tunnel walls }\end{array}$} & $\begin{array}{l}\text { Meso-Cenozoic } \\
\text { sand with } \\
\text { interlayers and } \\
\text { lenses of sandy } \\
\text { loam and loam; } \\
\text { mainly water- } \\
\text { saturated; confined } \\
\text { and unconfined } \\
\text { aquifers }\end{array}$ & $\begin{array}{l}\text { Weakly } \\
\text { permeable } \\
\text { Jurassic clay }\end{array}$ & $\begin{array}{l}\text { Carboniferous } \\
\text { terrigenic and } \\
\text { carbonate } \\
\text { deposits: } \\
\text { limestone, } \\
\text { dolomite, marl, } \\
\text { and clay. } \\
\text { Deposits } \\
\text { in the tunnel foot } \\
\text { watered with } \\
\text { confined } \\
\text { aquifers }\end{array}$ \\
\hline $\begin{array}{l}\text { Meso-Cenozoic } \\
\text { sand with } \\
\text { interlayers and } \\
\text { lenses of sandy } \\
\text { loam and loam; } \\
\text { mainly water- } \\
\text { saturated; confined } \\
\text { and unconfined } \\
\text { aquifers }\end{array}$ & Very high risk & Moderate risk & \\
\hline $\begin{array}{l}\text { Weakly permeable } \\
\text { Jurassic clay }\end{array}$ & & & \\
\cline { 3 - 4 } & & & \\
\hline $\begin{array}{l}\text { Carboniferous } \\
\text { terrigenic and } \\
\text { carbonate deposits: } \\
\text { limestone, } \\
\text { dolomite, marl, and } \\
\text { clay. Unevenly } \\
\text { watered with } \\
\text { confined aquifers. }\end{array}$ & & & \\
\hline
\end{tabular}

Fig. 5: The geological map risk for the construction and operation of shallow tunnels (at a depth of $20 \mathrm{~m}$ ). open-pit method in Moscow subsurface:

- Meso-Cenozoic sand with interlayers and lenses of sandy loam and loam (Quaternary, Cretaceous and Jurassic). For the most part, soils are water-saturated. Aquifers are confined and unconfined.

-Jurassic clay, weakly permeable.

-Carboniferous terrigenous and carbonate deposits: limestone, dolomite, marl, and clay. Unevenly watered with confined aquifers.

The combinations of these types in the walls and in the bottom of the tunnel result in 7 types of possible engineering geological conditions along the tunnel route (Fig. 6). The possible damage for the tunnel under construction was assessed proceeding from the analysis of the impact on it of such geohazards as groundwater and quicksand breakout to the construction pit, suffusion, and karst-suffosion processes. As a result, we distinguished and substantiated four risk categories: very high, high, moderate, and low. (Fig. 6). Very high geological risk is recognized for the construction and operation of tunnels in Meso-Cenozoic water-saturated sand, which is proved by many unfortunate cases of the shallow tunnel construction on Moscow. Meso-Cenozoic sand outcropping in the tunnel's walls gives rise to a high risk for an engineering structure irrespectively of the deposit types in the tunnel foot. Running a tunnel in the karstified Carboniferous deposits (limestone, dolomite, marl, and clay), due to their karstification and uneven watering with confined groundwater aquifers produces a moderate risk to engineering structures. A low risk is usually identified for the tunnels drawn in the low permeable Jurassic clay horizon.

According to this procedure, we have compiled the map of geological risk for the construction and operation of shallow tunnels (a depth of $20 \mathrm{~m}$ ) to a scale of 1: 100000 . The representative city territory within the Moscow ring highway was taken for this purpose, for which the $3 \mathrm{D}$ model of geoenvironment has been built, permitting us to analyze the geological structure of the area at any desired level to a depth of $100 \mathrm{~m}$ from the surface. These maps may be compiled for different tunnel depth, which permits to compare the alternative project options in the viewpoint of their safety and economic efficiency at the investment stage. 
The task of further studies is to develop mapping technologies and to substantiate scientifically the compilation of the integral map of geological risk for the future subsurface construction. This map may be compiled by superposition and the analysis of the risk maps for two or three levels of subsurface development The principal aim of this map is to reveal the zones at geological risk, within which a considerable damage may arise at any depth of laying engineering facility, and recommendations on special protective measures should be given. The 3-D model of Moscow geoenvironment permits obtaining actual data necessary for solving this problem.

\section{CONCLUSIONS}

Geological risk mapping is the principal method in risk analysis at the initial stages of projecting urban development. The performed studies in assessment and mapping of geological risk in Moscow attests to the diverse possibilities in the riskanalysis tool application to engineering geology of urban areas. Approaches to risk assessment differ depending on the purpose

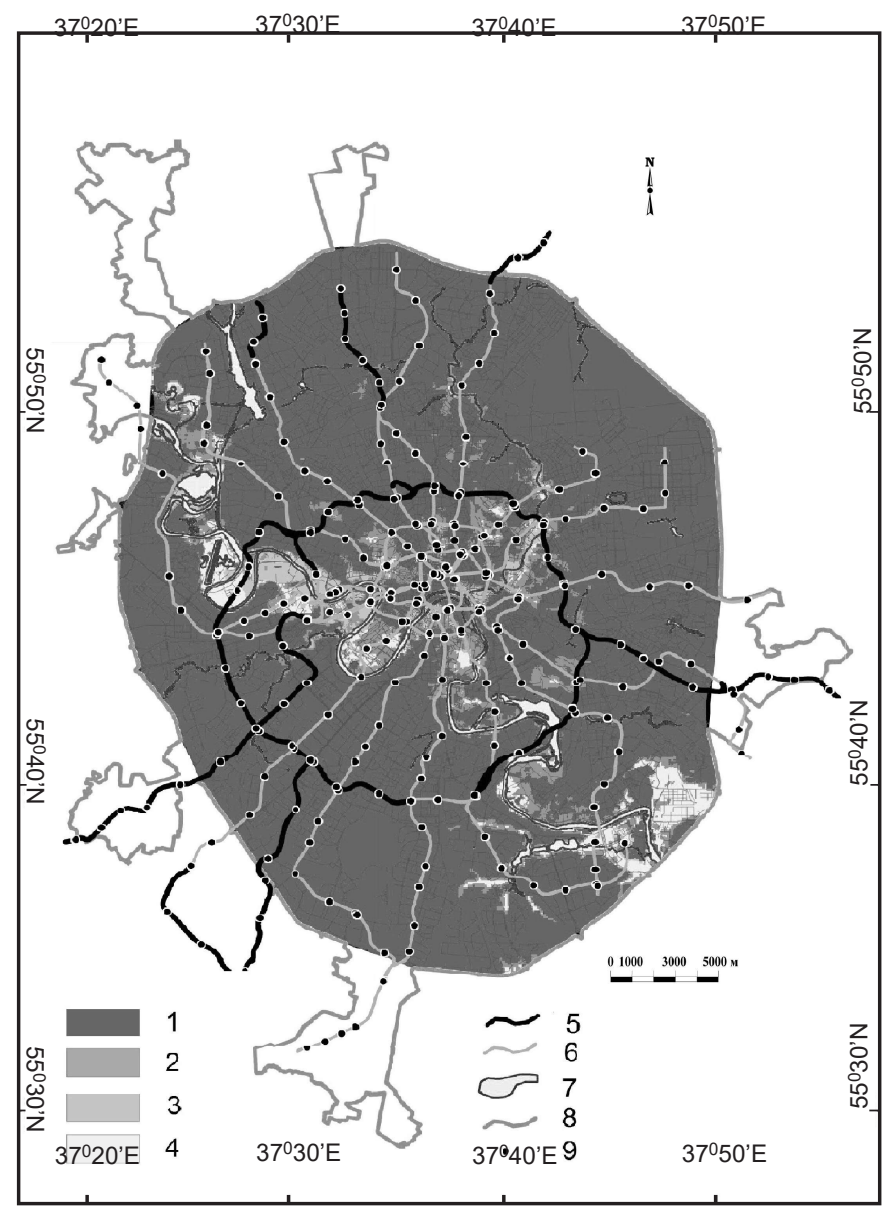

Fig. 6: The geological risk map for the construction of a metro tunnel at a depth of $20 \mathrm{~m}$ in Moscow. Designations: risk categories: 1-very high; 2-high; 3-moderate; 4-low; metro lines: 5-under construction; 6-in operation; 7-water bodies; 8-river channels; 9-metro stations. and scale of research. For the city territory, the result of riskanalysis most often consists in zoning the city territory on the basis of the risk level. It is hard to estimate quantitatively the level of geological risk, the more so, for the entire city territory. However, the qualitative comparative risk assessment also appears to be very important. For the entire city territory, geological risk is estimated as an integral characteristic of probable damage caused by geohazards and of technogenic load in this area. For a particular projected engineering structure, its risk is estimated as the value of probable expenses during its construction and operation. Geological risk mapping for future construction in cities appears to be a new approach in risk analysis. Application of this approach permits us to compare the alternative variants for driving linear engineering facilities (e.g., metro) in order to avoid substantial economic losses caused by geohazards. In cities, it is often difficult to change project decisions by moving construction to less risky geoenvironment. The purpose of the risk maps is to manage risks by predicting geohazard manifestations in the construction area and by giving recommendations on special protective measures for substantiating construction costs.

\section{ACKNOWLEDGEMENTS}

This study was supported by the Russian Science Foundation, project no. 16-17-00125.

\section{REFERENCES}

Clayton, C.R.I., 2009, Urban site investigation. In: Culshaw, M.G., Reeves, H.J. Jefferson, I. and Spink, T.W (eds.). Engineering Geology for Tomorrow's Cities. Geological Society, London, Engineering Geology Special Publication, v. 22, pp. 15-141.

Golodkovskaya, G.A. and Lebedeva N.I., 1984, Engineering geological zoning of Moscow. Inzhenernayageologiya. Engineering geology, v. 1984, 3, pp. 87-102. (in Russian)

Kalsnes, B., Nadim, F., and Lacasse, S., 2010, Managing geological risk. In: Geologically active, Williams, A.L., Pinches, G.M., Chin, C.Y., McMorran, T.J., and Massey, C.I. (eds.). Proceedings of the 11th IAEG Congress, Auckland, New Zealand, 5-10 September 2010, Taylor and Francis group, London, pp.111-126.

Knill, J., 2003, Core values: the first Hans-Cloos lecture. In: Bulletin of Engineering Geology and the Environment, v. 62 , no.1, pp. 1-34.

Koff, G.L., Likhacheva, E.A., and Timofeev, D.A., 2006, Geoecology of Moscow: methodology and methods of assessing the urban environment state. Moscow, MediaPress (in Russian).

Kozlyakova I., Eremina O., Anisimova N., and Kozhevnikova I., 2016, Study of geology and Carboniferous roof topography upon engineering geological mapping of Moscow territory. In: Eggers, M.J., Griffiths, J.S., Parry, 
S., and Culshaw, M.G. (eds.). Developments in Engineering Geology., Geological Society, London, Engineering Geology Special Publication, v. 27, pp. 45-53,

Kozlyakova, I.V., Mironov, O.K., and Eremina, O.N., 2015, Engineering Geological Zoning of Moscow by the conditions for subsurface construction. In: Proceedings 12th IAEG Congress, Turin, Italy. Springer, v. 5, pp. 923-926.

Kutepov, V.M., Anisimova, N.G., Eremina, O.N., Kozhevnikova, I.A., and Kozlyakova, I.V., 2011, The map of preQuaternary deposits as a base for large-scale geological mapping of Moscow territory. Geoekologiya (Environmental Geoscience), v. 5, pp. 399-411. (in Russian)

Marchiori-Faria, D.G. and Ferreira, C.J., 2006, Hazard mapping as part of civil defense preventive and contingency actions: a case study from Diadema, Brazil. In: Engineering Geology for Tomorrow's Cities. IAEG 2006, 6-10 Sept. 2006, CD-rom, paper no. 154.

Mora, S., 2010, Disasters should not be protagonists of Disaster Risk. In: Geologically active, Williams, A.L., Pinches, G.M., Chin, C.Y., McMorran, T.J., and Massey, C.I. (eds.). Proceedings of the 11th IAEG Congress, Auckland, New Zealand, 5-10 September 2010, Taylor and Francis group, London, pp.89-110.
Osipov, V. I., 2014, Large-scale thematic geological mapping of Moscow area. G. Lollino et. al. (eds.). Engineering Geology for Society and Territory. Springer International Publishing Switzerland, v. 5, pp. 11-16.

Osipov, V.I. and Medvedev, O.P. (eds.), 1997, Geology and the City. Moskovskie uchebniki I kartolitografiya Publ., Moscow, 400 p. (in Russian)

Osipov, V.I., 2008, Geological Conditions of Moscow Urban Development. ZAO Mir, Moscow, 36 p. (in Russian)

Ragozin A.L. and Yolkin V.A., 2006, Geological risks, formation and assessment in urbanized areas in Russia. In: Engineering Geology for Tomorrow's Cities. IAEG 2006, 6-10 Sept., CD-rom, paper no. 282.

Ragozin, A.L. (eds.), 2003, Natural hazards of Russia. Assessment and management of natural risks. 2003. Topical vol., Moscow: KRUK, 320p. (in Russian)

Zhang, F., Yang Q., Jia, X., Liu, J., and Wang, B., 2006, Landuse optimization by geological hazard assessment in Nanjing City, China. In: Engineering Geology for Tomorrow's Cities. IAEG 2006, 6-10 Sept. 2006, CDrom, paper no. 324 . 